\title{
Optical and Luminescence Spectroscopy of Varicolored Gem Spinel from Mogok, Myanmar and Lục Yên, Vietnam
}

\author{
Iveta Malíčková ${ }^{1}$, Peter Bačík ${ }^{1,2, * \mathbb{D}}$, Jana Fridrichová ${ }^{1}$, Radek Hanus ${ }^{3}$, L'udmila Illášová ${ }^{4}$, Ján Štubňa ${ }^{4}$ (D), \\ Daniel Furka ${ }^{5}$, Samuel Furka ${ }^{5}$ and Radek Škoda ${ }^{6}$ (D) \\ 1 Department of Mineralogy and Petrology, Faculty of Natural Sciences, Comenius University, Ilkovičova 6, \\ 84215 Bratislava, Slovakia; malickova3@uniba.sk (I.M.); jana.fridrichova@uniba.sk (J.F.) \\ 2 Earth Science Institute of the Slovak Academy of Science, Dúbravska Cesta 9, 84005 Bratislava, Slovakia \\ 3 Gemological Laboratory of e-gems.cz, 11000 Prague, Czech Republic; kakt@centrum.cz \\ 4 Gemmological Laboratory, Department of Geography and Regional Development, Faculty of Natural \\ Sciences, Constantine the Philosopher University in Nitra, Nábrežie mládeže 91, 94974 Nitra, Slovakia; \\ lillasova@ukf.sk (L'.I.); jstubna@ukf.sk (J.Š.) \\ 5 Department of Physical and Theoretical Chemistry, Faculty of Natural Sciences, Comenius University, \\ Ilkovičova 6, 84215 Bratislava, Slovakia; furka2@uniba.sk (D.F.); furka.samuel@gmail.com (S.F.) \\ 6 Department of Geological Sciences, Masaryk University, Kotlářská 2, 61137 Brno, Czech Republic; \\ rskoda@sci.muni.cz \\ * Correspondence: peter.bacik@uniba.sk
}

check for updates

Citation: Malíčková, I.; Bačík, P.; Fridrichová, J.; Hanus, R.; Illášová, L'.; Štubňa, J.; Furka, D.; Furka, S.; Škoda, R. Optical and Luminescence Spectroscopy of Varicolored Gem Spinel from Mogok, Myanmar and Lục Yên, Vietnam. Minerals 2021, 11, 169. https://doi.org/10.3390/ $\min 11020169$

Academic Editor:

Thomas Hainschwang

Received: 22 December 2020

Accepted: 3 February 2021

Published: 7 February 2021

Publisher's Note: MDPI stays neutral with regard to jurisdictional claims in published maps and institutional affiliations.

Copyright: (c) 2021 by the authors. Licensee MDPI, Basel, Switzerland. This article is an open access article distributed under the terms and conditions of the Creative Commons Attribution (CC BY) license (https:// creativecommons.org/licenses/by/ $4.0 /)$.
Abstract: We studied 12 crystal fragments of natural spinel from Mogok, Myanmar and Lục Yên, Vietnam. All samples were crystal fragments of various shapes and sizes and several of them had gemological quality. Studied samples are enriched in $\mathrm{Cr}, \mathrm{V}, \mathrm{Fe}^{2+}, \mathrm{Fe}^{3+}, \mathrm{Zn}$, which are responsible for its resulting color. They could be divided into groups of $\mathrm{V}-\mathrm{Cr}$ spinels with $\mathrm{Cr}$ 0.001-0.006 apfu, V 0.001-0.004 apfu, and Fe spinels containing increased $\mathrm{Fe}^{2+}(0.001-0.017 \mathrm{apfu})$ and $\mathrm{Fe}^{3+}(0.004-0.012 \mathrm{apfu})$. Some samples show luminescence bands at 677, 685, 697, 710, and $718 \mathrm{~nm}$ assigned to $\mathrm{Cr}^{3+}$. The optical absorption spectra of spinels were divided into two groups of $\mathrm{V}-\mathrm{Cr}$ and Fe spinels based on the dominant element acting on optical spectra. The optical spectrum of $\mathrm{V}-\mathrm{Cr}$ spinels can be divided into two zones (1) 420-550 nm ( $\mathrm{V}^{3+}$ and $\mathrm{Cr}^{3+}$ absorption); (2) 640-1000 nm $\left(\mathrm{Fe}^{2+}-\mathrm{Fe}^{3+}\right.$ charge transfer). The optical absorption spectra of $\mathrm{Fe}$ spinels can also be divided into two zones (1) 410-650 nm ( $\mathrm{Fe}^{2+}-\mathrm{Fe}^{3+}$ charge transfer) and (2) 770-1000 nm $\left(\mathrm{Fe}^{2+}\right)$. This variation in chromophores results in the differences in color: $\mathrm{V}-\mathrm{Cr}$ spinels are pink to red, Fe spinels are in shades of blue as well as yellow and pink.

Keywords: spinel; optical absorption spectroscopy; Raman spectroscopy; luminescence; chromophore; luminophore

\section{Introduction}

Due to their wide range of intense colors, high mechanical resistance, and high thermal and chemical stability, minerals belonging to the spinel group are actively sought as gemstones, while synthetic spinel powders are widely used as ceramic pigment. The variability in color displayed by spinels is due to their ability to accommodate a wide range of transition metal cations of different valence states at their structural sites ( $\mathrm{Fe}, \mathrm{Cr}, \mathrm{V}, \mathrm{Co}$, etc.) [1]. Spinel color is caused by impurities; without impurities it is colorless. Its color can be brown, black, red, orange, yellow, green, blue, indigo, or purple. The luster is glassy to matt, with a white scratch, the spinel is isotropic [2].

The spinel-supergroup minerals have the general formula $\mathrm{AB}_{2} \mathrm{X}_{4}$ [3], where $\mathrm{A}$ represents divalent and $\mathrm{B}$ trivalent cations at the tetrahedrally and octahedrally coordinated sites in a structure with a cubic nearly close-packed arrangement. In spinel, the A site is occupied by $\mathrm{Mg}$, B contains $\mathrm{Al}$, and $\mathrm{X}$ site is occupied by $\mathrm{O}$. Most natural and synthetic 
spinels are disordered, $\mathrm{Al}$ occupies tetrahedral site, and both $\mathrm{Al}$ and $\mathrm{Mg}$ occupies octahedral sites [4]. This disorder causes defects, electron traps, and vacancies in the crystal structure that complicate the interpretation of the spectra. In nature, the spinel can slowly cool enough to be arranged [5]. The cations occupy one-fourth of the tetrahedral interstices and half of the octahedral interstices in the cubic close packed array of oxide ions (space group Fd3m) [6]. The composition as well as cation distribution of spinel minerals and materials have a strong influence on their physical properties [7], as far as light absorption in concerned [1].

The goal of this paper is a multimethodological study of twelve spinel samples from two localities-Luc Yen, Vietnam and Mogok, Myanmar. These have a different coloring and chemical composition. Chromophores in spinel were identified by electron microprobe analysis (EMPA) and optical absorption spectroscopy (OAS) to determine the main chromophores or their combination causing the resulting mineral coloration. Similarly, the main luminophores were studied by Raman spectroscopy.

\section{Geological Settings}

The rich tectonic history of Southeast Asia developed during several deformation episodes related to the closure of the Paleo-Tethys Ocean and, later, to the Himalayan orogeny. The geology of northern Vietnam is dominated by metamorphic rocks (mainly medium-grade mica schist, marble, and granulitic gneisses) inherited from these two major orogenic events: the Indosinian orogeny, and the Himalayan collision [8].

All of Luc Yen's gem deposits are in the Lo Gam zone of Northern Vietnam. The structure of this unit results from the deformation of the Himalayan orogenesis superimposed on the pre-existing Indosinian structure [9]. The Lo Gam formation consists of a sedimentary series metamorphosed into marble, gneiss, calc-silicates, mica schist, and amphibolite. These metamorphic rocks are sometimes intruded by granitic and pegmatitic dykes [9-11]. The marbles are mainly calcitic and interlayered with $\mathrm{Al}-, \mathrm{V}-$, and $\mathrm{Cr}$-rich amphibolite. Blue spinel in these primary deposits is not associated with ruby or red spinel [12]. There are numerous deposits in this area including ruby and spinel deposits, also fine tourmaline, sapphire, amazonite, pargasite, and humite [13].

Mogok gem-rich area is located within the central part of the Metamorphic Belt in the Central Myanmar. This assemblage is composed of Paleozoic and Mesozoic high-grade metasediments and intrusive rocks [14-16] and forms part of the Mogok-Mandalay-Mergui belt. The Mogok Stone Tract is mainly composed of gneiss, marble, calc-silicate rocks and quartzite, intruded by various felsic to mafic igneous rocks [17]. Ruby, sapphire, and spinel are found in primary deposits (calc-silicate rocks and marbles, with spinel only forming in the latter) and secondary deposits such as alluvial and eluvial placers, as well as karstic sinkholes and caverns [18]. These are associated with beryl, actinolite, tourmaline, pargasite, phenakite, topaz, uvite, zircon, and many others [19].

\section{Materials and Methods}

We studied 12 crystal fragments of natural samples spinel from Mogok, Myanmar SP-M1 to 9 and Lục Yên, Vietnam SPV-1 to 3. Measurements were performed on unoriented samples.

The chemical composition of spinels and associated minerals was established using a Cameca SX100 electron microprobe in wavelength-dispersion mode at the Masaryk University (Brno, Czech Republic), Department of Geological Sciences, under the following conditions: accelerating voltage $15 \mathrm{kV}$, beam current $20 \mathrm{nA}$, and beam diameter $3 \mu \mathrm{m}$. The samples were analyzed with the following standards: hematite $(\mathrm{Fe} \mathrm{Ka}), \mathrm{Mn}_{2} \mathrm{SiO}_{4}$ ( $\mathrm{Mn} \mathrm{Ka}), \mathrm{TiO}(\mathrm{Ti} \mathrm{Ka})$, wollastonite ( $\mathrm{Ca} \mathrm{Ka})$, andalusite $(\mathrm{Al} \mathrm{Ka}), \mathrm{Mg}_{2} \mathrm{SiO}_{4}(\mathrm{Mg} \mathrm{Ka})$, titanite ( $\mathrm{Si} \mathrm{Ka}$ ), chromite (Cr Ka), gahnite ( $\mathrm{Zn} \mathrm{Ka}$ ), vanadinite ( $\mathrm{V} \mathrm{Ka}), \mathrm{Ni}_{2} \mathrm{SiO}_{4}(\mathrm{Ni} \mathrm{Ka})$, Co (Co $\mathrm{Ka})$. The measured element detection limits ranged from 150 to $700 \mathrm{ppm}$. The spinel crystal-chemical formula was calculated based on 3 cations per formula unit, the $\mathrm{Fe}^{2+} / \mathrm{Fe}^{3+}$ ratio was calculated from the charge-balanced formula. 
Raman spectroscopy was performed by a LabRAM-HR Evolution (Horiba Jobin-Yvon) spectrometer system with a Peltier cooled CCD detector and Olympus BX-41 microscope (Department of Geological Sciences, Masaryk University, Brno, Czech Republic). Raman spectra were excited by $473 \mathrm{~nm}$ frequency-doubled diode laser with power of $2.5 \mathrm{~mW}$, dispersed by diffraction grating with density $600 \mathrm{gr} / \mathrm{mm}$ and a $520.6 \mathrm{~cm}^{-1}$ silicon wafer enabled spectral calibration. Spectra ranged from 100 to $10,000 \mathrm{~cm}^{-1}$ with acquisition time of $15 \mathrm{~s}$ per frame and 2 accumulations.

Optical (Vis-NIR) absorption spectra of samples in the region $(400-750 \mathrm{~nm})$ were measured with the GL Gem SpectrometerTM at room temperature in the Gemological Institute of Constantine the Philosopher University, Nitra, Slovakia. The UV absorption spectra of the polished samples within the regime 197-400 $\mathrm{nm}$ and resolution $1 \mathrm{~nm}$, were measured using PERKIN-ELMER Lambda 35 UV/VIS double beam spectrophotometer in absorption mode, reference to air and $1 \mathrm{~nm}$ slit width at Faculty of Natural Sciences, Comenius University (Bratislava, Slovakia).

Both Raman and UV/Vis/NIR spectra were processed in Seasolve PeakFit 4.1.12 software. Raman and absorption bands were fitted by Voigt function with automatic background correction and Savitzky-Golay smoothing.

\section{Results}

We studied 12 crystal fragments of natural spinel from Mogok SP-M-1 to 9 and Lục Yên, Vietnam SPV-1 to 3 (Table 1). All samples were crystal fragments of various shapes and sizes and several of them had gemological quality.

Table 1. Electron microprobe analyses of spinels, first provided in wt. \% of elements and then recalculated on the basis of 3 anions, the $\mathrm{Fe}^{2+} / \mathrm{Fe}^{3+}$ ratio calculated from the charge-balanced formula.

\begin{tabular}{|c|c|c|c|c|c|c|c|c|c|c|c|c|}
\hline & SP-M1 & SP-M2 & SP-M3 & SP-M4 & SP-M5 & SP-M6 & SP-M7 & SP-M8 & SP-M9 & SPV-1 & SPV-2 & SPV-3 \\
\hline $\mathrm{SiO}_{2}$ & 0.05 & 0.07 & 0.08 & 0.04 & 0.06 & 0.02 & 0.05 & 0.04 & 0.05 & 0.03 & 0.06 & 0.04 \\
\hline $\mathrm{TiO}_{2}$ & 0.01 & 0.01 & 0.01 & 0.03 & 0.14 & 0.00 & 0.00 & 0.00 & 0.01 & 0.04 & 0.00 & 0.08 \\
\hline $\mathrm{Al}_{2} \mathrm{O}_{3}$ & 71.28 & 71.64 & 71.29 & 71.48 & 71.12 & 71.06 & 70.27 & 70.36 & 70.80 & 70.87 & 70.52 & 70.86 \\
\hline $\mathrm{V}_{2} \mathrm{O}_{3}$ & 0.12 & 0.12 & 0.01 & 0.08 & 0.24 & 0.11 & 0.04 & 0.05 & 0.01 & 0.19 & 0.06 & 0.07 \\
\hline $\mathrm{Cr}_{2} \mathrm{O}_{3}$ & 0.00 & 0.06 & 0.07 & 0.04 & 0.07 & 0.02 & 0.04 & 0.03 & 0.02 & 0.17 & 0.31 & 0.12 \\
\hline $\mathrm{Fe}_{2} \mathrm{O}_{3}$ & 0.14 & 0.03 & 0.20 & 0.11 & 0.22 & 0.15 & 0.65 & 0.36 & 0.38 & 0.22 & 0.46 & 0.35 \\
\hline $\mathrm{FeO}$ & 0.12 & 0.05 & 0.05 & 0.00 & 0.11 & 0.00 & 0.85 & 0.65 & 0.11 & 0.08 & 0.00 & 0.31 \\
\hline $\mathrm{MnO}$ & 0.00 & 0.01 & 0.00 & 0.00 & 0.00 & 0.00 & 0.01 & 0.00 & 0.00 & 0.02 & 0.01 & 0.02 \\
\hline $\mathrm{MgO}$ & 28.12 & 28.23 & 28.19 & 28.25 & 28.30 & 28.39 & 27.34 & 27.49 & 28.01 & 28.08 & 28.18 & 27.92 \\
\hline $\mathrm{ZnO}$ & 0.11 & 0.16 & 0.06 & 0.33 & 0.00 & 0.07 & 0.28 & 0.13 & 0.03 & 0.11 & 0.10 & 0.26 \\
\hline $\mathrm{NiO}$ & 0.01 & 0.01 & 0.01 & 0.03 & 0.03 & 0.00 & 0.00 & 0.00 & 0.00 & 0.02 & 0.00 & 0.00 \\
\hline $\mathrm{CoO}$ & 0.02 & 0.05 & 0.00 & 0.00 & 0.00 & 0.00 & 0.00 & 0.00 & 0.02 & 0.02 & 0.00 & 0.00 \\
\hline $\mathrm{CaO}$ & 0.01 & 0.00 & 0.01 & 0.02 & 0.01 & 0.01 & 0.00 & 0.00 & 0.00 & 0.00 & 0.01 & 0.00 \\
\hline Total & 99.98 & 100.44 & 99.99 & 100.40 & 100.31 & 99.82 & 99.54 & 99.12 & 99.42 & 99.83 & 99.71 & 100.02 \\
\hline $\mathrm{Si}^{4+}$ & 0.001 & 0.002 & 0.002 & 0.001 & 0.001 & 0.001 & 0.001 & 0.001 & 0.001 & 0.001 & 0.001 & 0.001 \\
\hline $\mathrm{Al}^{3+}$ & 1.995 & 1.996 & 1.994 & 1.992 & 1.985 & 1.989 & 1.987 & 1.992 & 1.993 & 1.988 & 1.981 & 1.987 \\
\hline $\mathrm{V}^{3+}$ & 0.002 & 0.002 & 0.000 & 0.002 & 0.004 & 0.002 & 0.001 & 0.001 & 0.000 & 0.004 & 0.001 & 0.001 \\
\hline $\mathrm{Cr}^{3+}$ & 0.000 & 0.001 & 0.001 & 0.001 & 0.001 & 0.000 & 0.001 & 0.001 & 0.000 & 0.003 & 0.006 & 0.002 \\
\hline $\mathrm{Fe}^{3+}$ & 0.003 & 0.001 & 0.004 & 0.002 & 0.006 & 0.003 & 0.012 & 0.006 & 0.007 & 0.005 & 0.008 & 0.009 \\
\hline $\mathrm{Ti}^{4+}$ & 0.000 & 0.000 & 0.000 & 0.000 & 0.000 & 0.000 & 0.000 & 0.000 & 0.000 & 0.000 & 0.000 & 0.000 \\
\hline $\mathrm{Mg}^{2+}$ & 0.000 & 0.000 & 0.000 & 0.003 & 0.003 & 0.006 & 0.000 & 0.000 & 0.000 & 0.000 & 0.003 & 0.000 \\
\hline B & 2.000 & 2.000 & 2.000 & 2.000 & 2.000 & 2.000 & 2.000 & 2.000 & 2.000 & 2.000 & 2.000 & 2.000 \\
\hline $\mathrm{Ti}^{4+}$ & 0.000 & 0.000 & 0.000 & 0.000 & 0.003 & 0.000 & 0.000 & 0.000 & 0.000 & 0.001 & 0.000 & 0.002 \\
\hline $\mathrm{Fe}^{2+}$ & 0.002 & 0.001 & 0.001 & 0.000 & 0.000 & 0.000 & 0.017 & 0.013 & 0.002 & 0.000 & 0.000 & 0.003 \\
\hline $\mathrm{Mn}^{2+}$ & 0.000 & 0.000 & 0.000 & 0.000 & 0.000 & 0.000 & 0.000 & 0.000 & 0.000 & 0.000 & 0.000 & 0.000 \\
\hline $\mathrm{Mg}^{2+}$ & 0.995 & 0.995 & 0.998 & 0.993 & 0.996 & 0.998 & 0.978 & 0.984 & 0.997 & 0.996 & 0.998 & 0.990 \\
\hline $\mathrm{Zn}^{2+}$ & 0.002 & 0.003 & 0.001 & 0.006 & 0.000 & 0.001 & 0.005 & 0.002 & 0.000 & 0.002 & 0.002 & 0.005 \\
\hline $\mathrm{Ni}^{2+}$ & 0.000 & 0.000 & 0.000 & 0.000 & 0.001 & 0.000 & 0.000 & 0.000 & 0.000 & 0.000 & 0.000 & 0.000 \\
\hline $\mathrm{Co}^{2+}$ & 0.000 & 0.001 & 0.000 & 0.000 & 0.000 & 0.000 & 0.000 & 0.000 & 0.000 & 0.000 & 0.000 & 0.000 \\
\hline $\mathrm{Ca}^{2+}$ & 0.000 & 0.000 & 0.000 & 0.000 & 0.000 & 0.000 & 0.000 & 0.000 & 0.000 & 0.000 & 0.000 & 0.000 \\
\hline$A$ & 1.000 & 1.000 & 1.000 & 1.000 & 1.000 & 1.000 & 1.000 & 1.000 & 1.000 & 1.000 & 1.000 & 1.000 \\
\hline
\end{tabular}




\subsection{Chemical Composition}

The most abundant elements in the spinel samples are $\mathrm{Al}$ and $\mathrm{Mg}$ corresponding to the mineral formula of spinel end member (Table 2). Spinel is enriched in $\mathrm{Cr}, \mathrm{V}, \mathrm{Fe}^{2+}, \mathrm{Fe}^{3+}$, and $\mathrm{Zn}$, which are responsible for its resulting color. $\mathrm{V}$ and Cr-bearing spinels (SP-M1, 2, 4, 5, and 6, and SPV-1, 2, and 3) contain increased Cr (0.001-0.006 apfu), V (0.001-0.004 apfu), and low content of $\mathrm{Fe}^{2+}$ and $\mathrm{Fe}^{3+}$. Fe-bearing spinels (SP-M3, 7, 8, and 9) contain increased $\mathrm{Fe}^{2+}(0.001-0.017 \mathrm{apfu}), \mathrm{Fe}^{3+}(0.004-0.012 \mathrm{apfu})$.

\subsection{Raman Spectra}

The Raman bands of spinel (Figure 1) were assigned according to [20] (Table 3). The 308-312 and $662-665 \mathrm{~cm}^{-1}$ band are attributed to $T_{2 \mathrm{~g}}$ symmetry, $404-406 \mathrm{~cm}^{-1}$ band to $E_{\mathrm{g}}$ symmetry, $763-767 \mathrm{~cm}^{-1}$ bands to $\mathrm{A}_{1 \mathrm{~g}}$ symmetry. The measured values have deviations of up to $5 \mathrm{~cm}^{-1}$ compared to the reference literature. Measured Raman spectra also differ from published by the absence of some vibrations, depending on the sample orientation relative to the laser beam.

Table 2. Raman shifts $\left(\mathrm{cm}^{-1}\right)$ of Raman-active bands in the studied samples. Assignment of the spinel band modes was made according to [20].

\begin{tabular}{|c|c|c|c|c|c|c|c|}
\hline Mineral & Symmetry & SP-M1 & SP-M2 & SP-M3 & SP-M4 & SP-M5 & SP-M6 \\
\hline \multirow{3}{*}{ Spinel } & \multirow{3}{*}{$\mathrm{T}_{2 \mathrm{~g}}$} & \multirow{3}{*}{311} & \multirow{3}{*}{312} & \multirow{3}{*}{312} & \multirow{3}{*}{311} & 141 & 143 \\
\hline & & & & & & 308 & 309 \\
\hline & & & & & & 354 & \\
\hline \multirow[t]{2}{*}{ Spinel } & \multirow{2}{*}{$\mathrm{E}_{\mathrm{g}}$} & \multirow[t]{2}{*}{406} & \multirow[t]{2}{*}{406} & \multirow[t]{2}{*}{406} & \multirow[t]{2}{*}{406} & 404 & \multirow[t]{2}{*}{404} \\
\hline & & & & & & 437 & \\
\hline Spinel & $\mathrm{T}_{2 \mathrm{~g}}$ & 664 & 665 & 665 & 664 & 662 & 664 \\
\hline \multirow[t]{3}{*}{ Spinel } & $A_{1 g}$ & 766 & 767 & 766 & 766 & 764 & 763 \\
\hline & & & & & \multicolumn{3}{|c|}{1005} \\
\hline & & SP-M7 & SP-M8 & SP-M9 & SPV-1 & SPV-2 & SPV-3 \\
\hline Calcite/Dolomite & & & & 141 & & & \\
\hline Calcite/Dolomite & & & & 277 & & & \\
\hline Spinel & $\mathrm{T}_{2 \mathrm{~g}}$ & 309 & 310 & 309 & 311 & 311 & 310 \\
\hline Spinel & $\mathrm{E}_{\mathrm{g}}$ & 404 & 404 & 405 & 406 & 406 & 406 \\
\hline Spinel & $\mathrm{T}_{2 \mathrm{~g}}$ & 664 & 665 & 664 & 664 & 665 & 664 \\
\hline Spinel & $A_{1 g}$ & 765 & 765 & 765 & 766 & 766 & 766 \\
\hline Calcite/Dolomite & & & & 1086 & & & \\
\hline
\end{tabular}

Table 3. Color of the spinel samples and dominant chromophore.

\begin{tabular}{|c|c|c|c|}
\hline Sample & Provenance & Color & Determined Chromophore \\
\hline SP-M1 & Mogok, Myanmar & Light grayish pink & Vanadium-chromium \\
\hline SP-M2 & Mogok, Myanmar & pale orange & Vanadium-chromium \\
\hline SP-M3 & Mogok, Myanmar & very pale pink & $\operatorname{Iron}\left(\mathrm{Fe}^{3+}\right)$ \\
\hline SP-M4 & Mogok, Myanmar & purplish pink & Vanadium-chromium \\
\hline SP-M5 & Mogok, Myanmar & very dark red & Vanadium-chromium \\
\hline SP-M6 & Mogok, Myanmar & very soft orange & Vanadium-chromium \\
\hline SP-M7 & Mogok, Myanmar & very dark cyan & $\operatorname{Iron}\left(\mathrm{Fe}^{2+}\right)$ \\
\hline SP-M8 & Mogok, Myanmar & dark blue & Iron $\left(\mathrm{Fe}^{2+}\right)$ \\
\hline SP-M9 & Mogok, Myanmar & light grayish yellow & Iron $\left(\mathrm{Fe}^{3+}\right)$ \\
\hline SPV-1 & Lục Yên, Yên Bái, Vietnam & reddish pink & Vanadium-chromium \\
\hline SPV-2 & Lục Yên, Yên Bái, Vietnam & strong pink & Chromium-vanadium \\
\hline SPV-3 & Lục Yên, Yên Bái, Vietnam & grayish pink & Chromium-vanadium \\
\hline
\end{tabular}



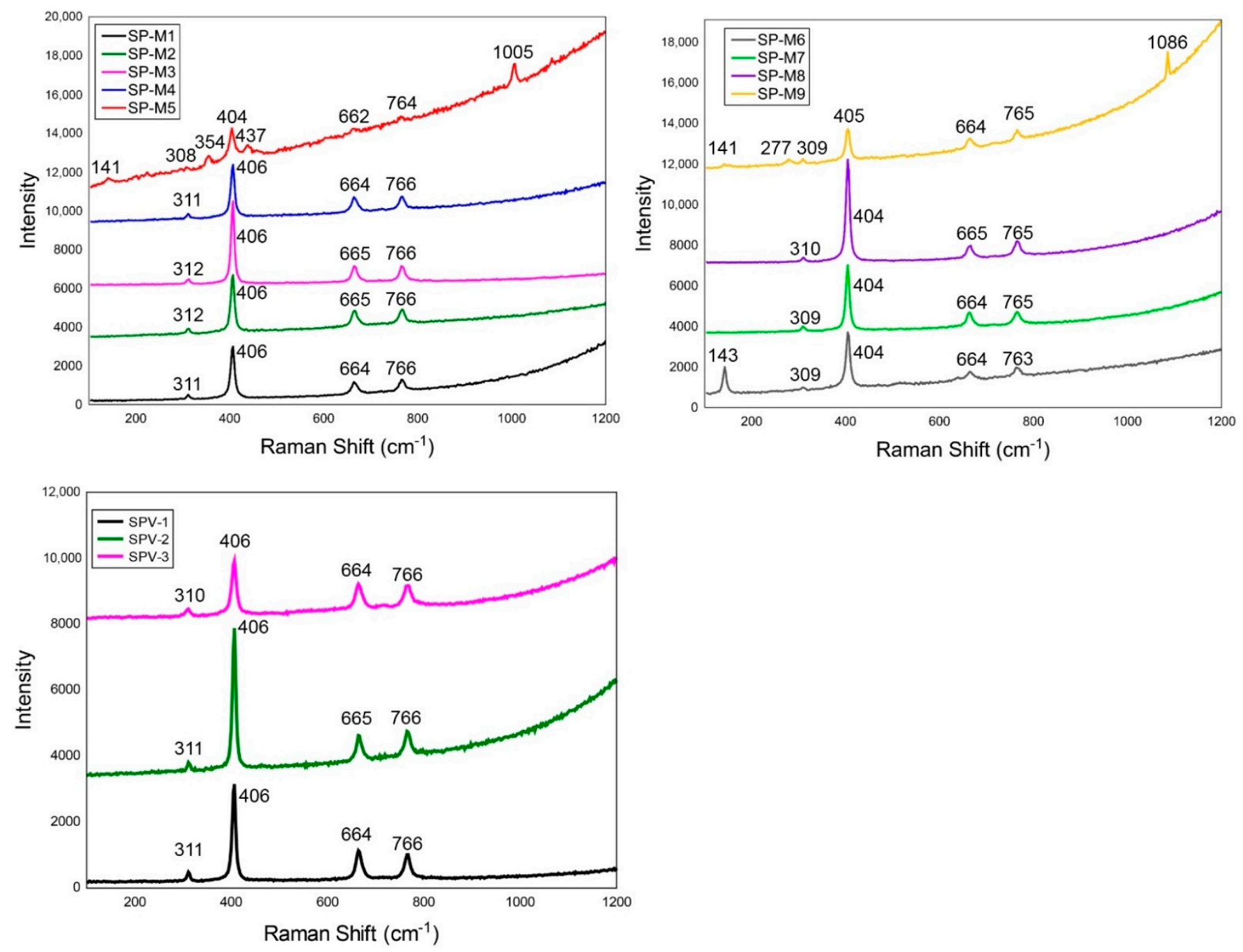

Figure 1. Raman spectra of the spinel samples (from left to right) SP-M1 to 9 from Mogok, SPV-1 to 3 from Vietnam.

\subsection{Luminescence Spectra}

Luminescence spectra of the spinel samples SP-M1 to 9 and SPV-1 to 3 was measured on the Raman spectrometer with $432 \mathrm{~nm}$ laser. The most intensive region in the luminescence spectra (Figure 2) of spinels is between 650 and $730 \mathrm{~nm}$, with the most intensive bands at $686-687 \mathrm{~nm}$. The luminescence region can be divided into five parts: (1) region 650-680 nm with the most intensive luminescence in the area $675-677 \mathrm{~nm}$; (2) region 680-690 $\mathrm{nm}$ with the most intensive luminescence in the area $686-687 \mathrm{~nm}$; (3) region $690-705 \mathrm{~nm}$ with maximum at $698 \mathrm{~nm}$; (4) region $705-715 \mathrm{~nm}$ with maximum at $707 \mathrm{~nm}$ (5) region 715-730 nm with maximum at $717 \mathrm{~nm}$. Luminescence bands at 677, 685, 697, 710, and $718 \mathrm{~nm}$ were assigned to $\mathrm{Cr}^{3+}$ according to [21]. The luminescence spectra of spinels have a major difference in intensity, due to the influence of luminophores.

\subsection{Optical Absorption Spectroscopy}

The optical absorption spectra of spinels were measured separately in UV and Vis-NIR regions. All spectra display presence of the intensive broad band (absorption edge) below $300 \mathrm{~nm}$ which can be attributed to ligand-metal charge transfer of both $\mathrm{O}^{2-} \rightarrow \mathrm{Fe}^{2+}$ and $\mathrm{O}^{2-} \rightarrow \mathrm{Fe}^{3+}$. Moreover, SP-M1 and SPV-2 samples have also relatively broad bands, but significantly less-intensive bands at 360-380 $\mathrm{nm}$ caused by spin-allowed electronic $d-d$ transitions ${ }^{4} A_{2 g} \rightarrow{ }^{4} T_{1 g}(\mathrm{~F})$ in $\mathrm{Cr}^{3+}$ at the $M$ sites. 
Based on the spectral features in the Vis-NIR region, samples can be divided into two groups $\mathrm{V}-\mathrm{Cr}$ (with $\mathrm{V}-\mathrm{Cr}$ spinels divided according to the chromophore dominance into $\mathrm{V}-\mathrm{Cr}$ or $\mathrm{Cr}-\mathrm{V}$ spinels) and Fe spinels $\left(\mathrm{Fe}^{2+}\right.$ dominated and $\mathrm{Fe}^{3+}$ dominated), based on the dominant element acting on optical spectra. Vanadium-chromium spinels have two major absorption bands and a third less intense absorption band (Figure 3; Table 4). Therefore, the optical spectrum can be divided into two zones (1) $420-550 \mathrm{~nm}$; (2) 640-1000 nm. In the first zone, there are two significant absorption bands which are caused by the $\mathrm{V}^{3+}$ and $\mathrm{Cr}^{3+}$. The second absorption features occur in the infrared region due to electron intervalence charge transfers (IVCT) $\mathrm{Fe}^{2+} \leftrightarrow \mathrm{Fe}^{3+}$ and $\mathrm{Fe}^{2+}$ [22]. The most intensive absorption band is in the violet-blue to blue region and the green to yellow-green region. There is less intensive absorption band in the near infrared and ultraviolet regions.
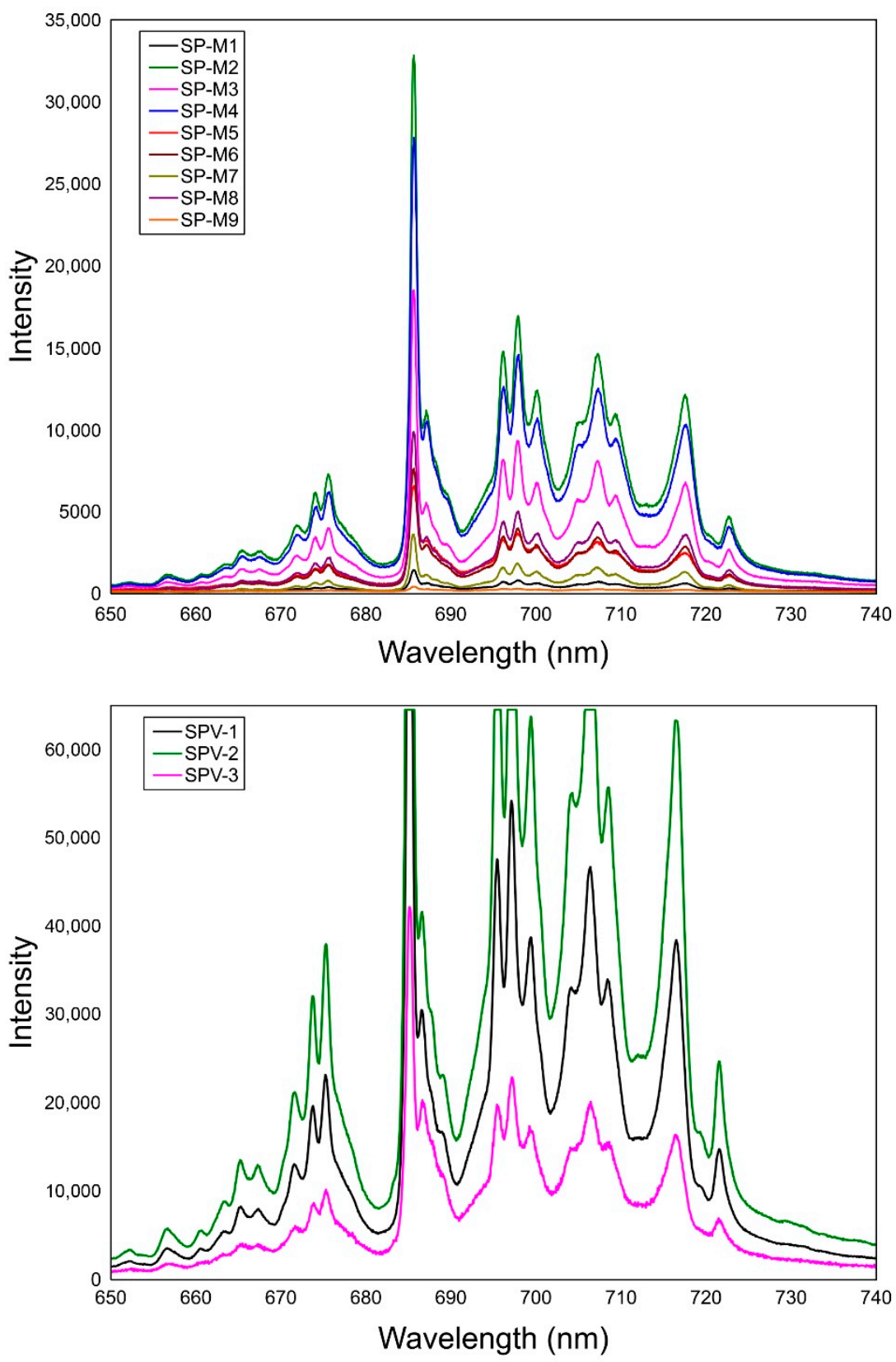

Figure 2. Luminescence spectra of the spinel samples SP-M1 to 9 from Mogok and SPV-1 to 3 from Vietnam measured on the Raman spectrometer with $432 \mathrm{~nm}$ laser. 

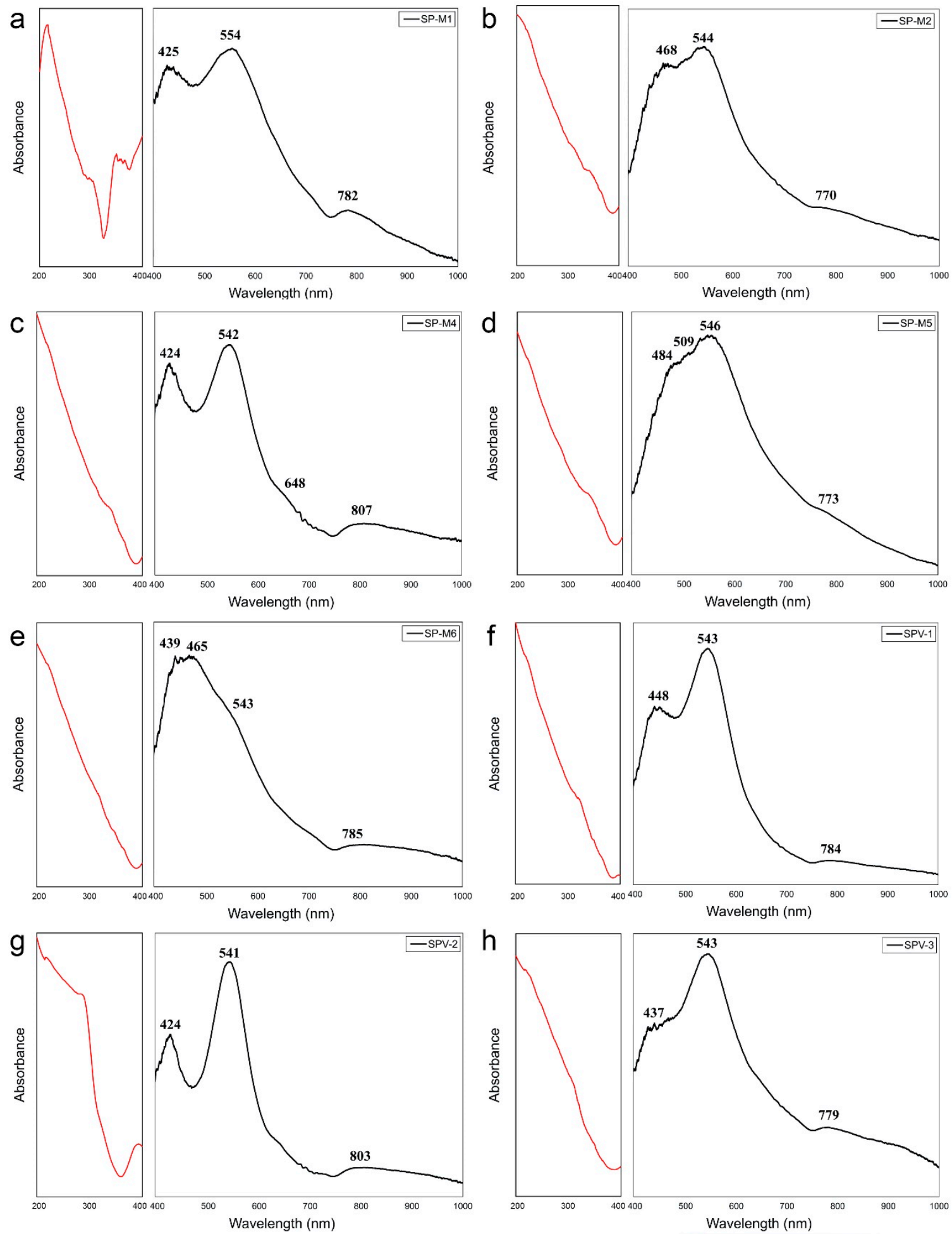

Figure 3. Optical absorption spectra of the V and Cr spinels: vanadium-dominant (a-e); chromium-dominant (f-h).

The optical spectra of Fe-spinels (Figure 4, Table 5) are different, they are more complicated, and they have more absorption regions. In this case, the absorption can also be divided into two zones (1) $410-650 \mathrm{~nm}$ and (2) $770-1000 \mathrm{~nm}$. In the first zone, there are two absorption regions at $422-464 \mathrm{~nm}$ and $541-647 \mathrm{~nm}$, the most intense absorption bands at 541, 553 (SP-M3, SP-M8) and $461 \mathrm{~nm}$ (SP-M7, SP-M9). This zone belongs to IVCT $\mathrm{Fe}^{2+} \leftrightarrow \mathrm{Fe}^{3+}$ and $\mathrm{Fe}^{2+}$. The third region, the infrared region, with two absorption bands at 770-795 and 908-932 nm, is due to $\mathrm{Fe}^{2+}$ [22]. The most intense absorptions are in the 
violet-blue to blue, yellow green to red, and weak absorption in the ultraviolet and near infrared regions.

Table 4. Assignment of the absorption bands for V and Cr spinel samples to chromophores.

\begin{tabular}{|c|c|c|c|c|c|c|c|c|}
\hline SP-M1 & SP-M2 & SP-M4 & SP-M5 & SP-M6 & SPV-1 & SPV-2 & SPV-3 & Assignment \\
\hline 398 & & 399 & 396 & 397 & 399 & 397 & & $\mathrm{~V}^{3}$ \\
\hline 425 & & 424 & 484 & 439 & 448 & 424 & 437 & $\mathrm{~V}^{3+}, \mathrm{Cr}^{3+}$ \\
\hline & 468 & & 509 & 465 & & & & $\mathrm{Cr}^{3+}$ \\
\hline 554 & 544 & $\begin{array}{l}542 \\
648\end{array}$ & 546 & 543 & 543 & 541 & 543 & $\mathrm{~V}^{3+}, \mathrm{Cr}^{3+}$ \\
\hline 782 & 770 & 807 & 773 & 785 & 784 & 803 & 779 & $\begin{array}{l}\mathrm{Fe}^{2+} \\
\mathrm{Fe}^{2+}\end{array}$ \\
\hline
\end{tabular}

a
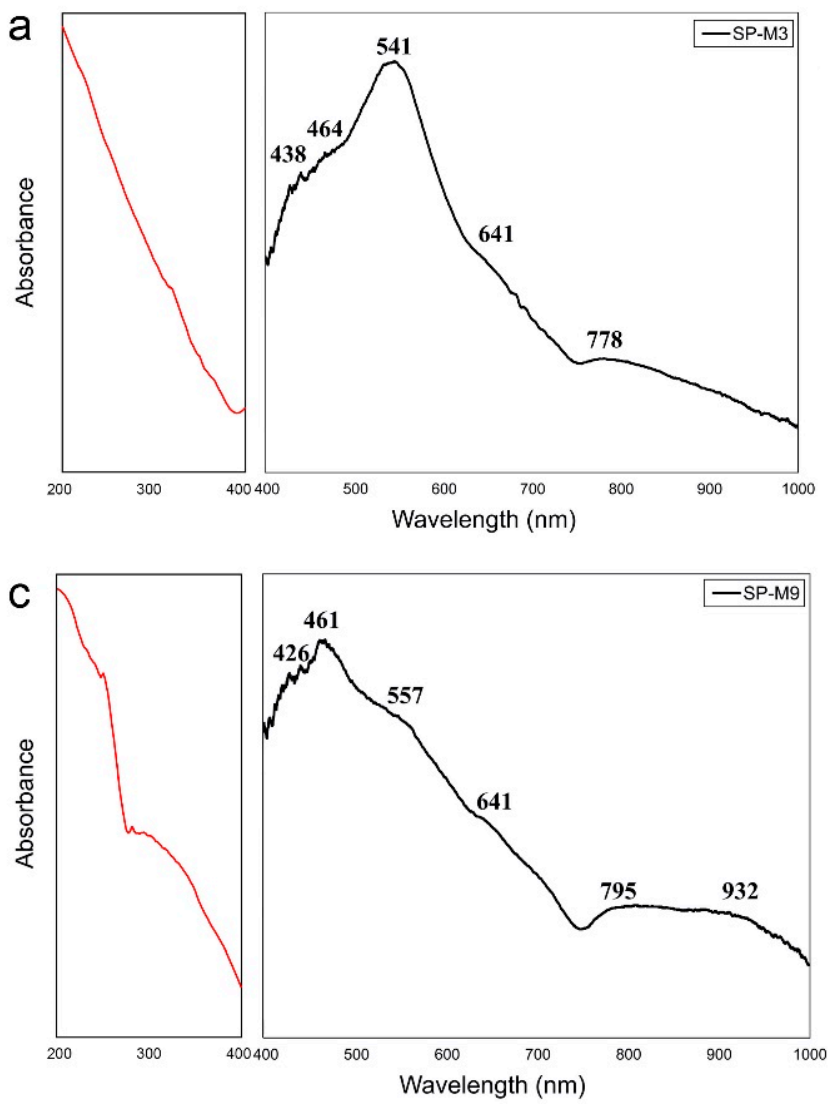
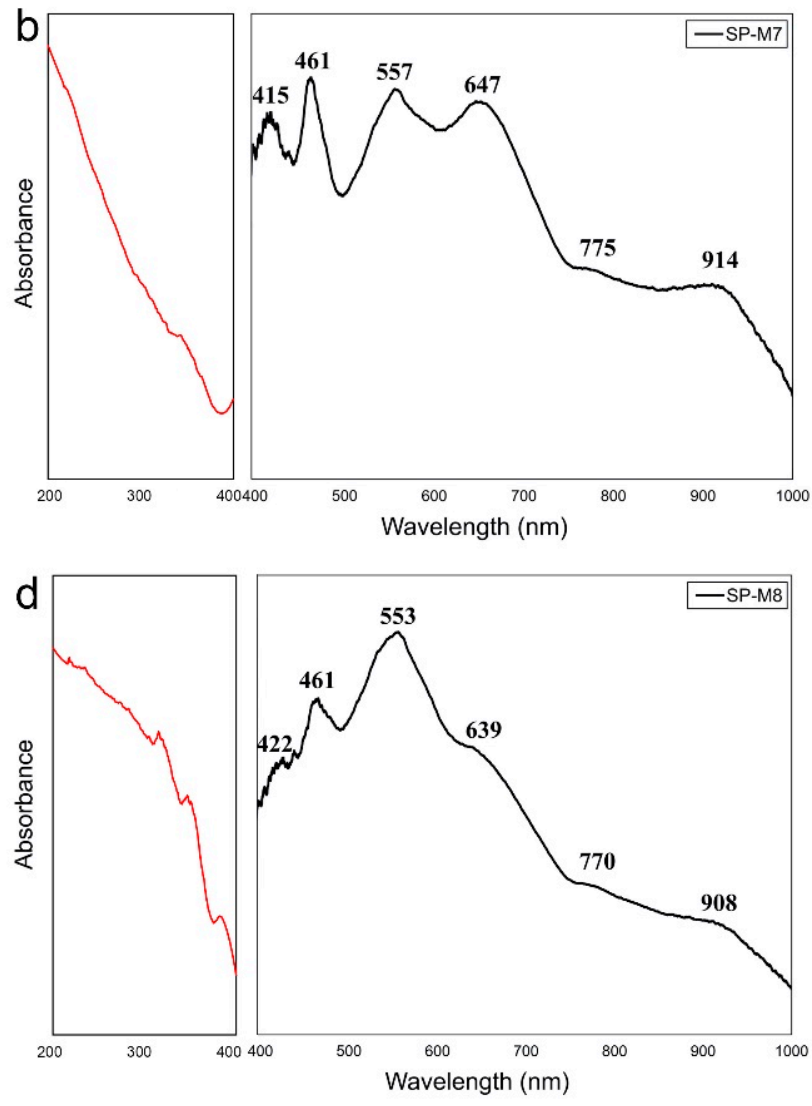

Figure 4. Optical absorption spectra of Fe spinels: $\mathrm{Fe}^{3+}$-dominant (a,d); $\mathrm{Fe}^{2+}$-dominant $(\mathbf{b}, \mathbf{c})$.

Table 5. Assignment of the absorption bands for Fe spinel samples to chromophores.

\begin{tabular}{ccccc}
\hline SP-M3 & SP-M7 & SP-M8 & SP-M9 & Assignment \\
\hline 438 & 415 & 422 & 426 & $\mathrm{Fe}^{2+}$ \\
464 & 461 & 461 & 461 & $\mathrm{Fe}^{3+}$ \\
541 & 557 & 553 & 557 & $\mathrm{Fe}^{2+}$ \\
641 & 647 & 639 & 641 & $\mathrm{IVCT} \mathrm{Fe}^{2+} \leftrightarrow \mathrm{Fe}^{3+}$ \\
778 & 775 & 770 & 795 & $\mathrm{Fe}^{2+}$ \\
& 914 & 908 & 932 & $\mathrm{Fe}^{2+}$ \\
\hline
\end{tabular}




\section{Discussion}

\subsection{Raman Spectroscopy}

The molecular vibrations in spinel supergroup belong to the following symmetry species: $A_{1 g}(R)+E_{g}(R)+F_{1 g}+3 F_{2 g}(R)+2 A_{2 u}+2 E_{u}+5 F_{1 u}(I R)+2 F_{2 u}$, where $R$ (Raman active) and IR (infrared active) denote spectral activity. Spinel structure has a symmetry center; therefore, the active modes exclude each other. Five of the nine optical modes, $1 \mathrm{~A}_{\mathrm{g}}+1 \mathrm{E}_{\mathrm{g}}+3 \mathrm{~T}_{2 \mathrm{~g}}$, are Raman active, and four, $1 \mathrm{~A}_{\mathrm{g}}+1 \mathrm{E}_{\mathrm{g}}+3 \mathrm{~T}_{2 \mathrm{~g}}$, are infrared active $[5,20]$.

However, only four Raman bands have been reported for a natural spinel. The missing fifth band at $492 \mathrm{~cm}^{-1}$ was obtained only in the spectrum of synthetic spinel. When the sample is heated, a band appears in the spectrum at $727 \mathrm{~cm}^{-1}$ [5].

Spinel has Raman vibrational modes in the spectral region from 100 to $800 \mathrm{~cm}^{-1}$. We observed strong Raman bands in the regions of $400-500 \mathrm{~cm}^{-1}$, and $700-800 \mathrm{~cm}^{-1}$; these were attributed to $\mathrm{E}_{\mathrm{g}}$ and $\mathrm{A}_{1 \mathrm{~g}}$, respectively.

Some studied samples-SP-M5, 6, and 9-exhibited different bands than commonly found in published Al-spinel literature [5,23-25]. It is possible that during the measurement, some mineral inclusion, which was located below the surface of the sample and, therefore, not detected by EMPA, was measured.

Since Mogok spinels are formed in marbles, or carbonates, there is a probable occurrence of Ca-mineral inclusions in spinels. They were typically present as colorless, irregularly shaped inclusions. In the sample SP-M9, we recorded calcite or dolomite inclusions. Raman bands at 141,277 , and $1086 \mathrm{~cm}^{-1}$ are consistent with the published data [26]. The band at $1086 \mathrm{~cm}^{-1}$ is assigned to the $v_{1}\left(\mathrm{CO}_{3}\right)^{2-}$ symmetric stretching mode. Bands at 141 and $277 \mathrm{~cm}^{-1}$ are at lower wavelengths and are the result of external group vibrations $\left(\mathrm{CO}_{3}\right)^{2-}$, which include rotational and translational oscillation of these groups [27].

Identification of the $143 \mathrm{~cm}^{-1}$ Raman band origin in SP-M6 is more complicated. It may be $\left(\mathrm{CO}_{3}\right)^{2-}$ vibration in carbonate, while other bands did not manifest in the spectrum due to crystal orientation. However, it could also be a different inclusion, possibly anatase. Weak Raman bands were reflected in the area at 510 and $635 \mathrm{~cm}^{-1}$, which are consistent with the published data of spinel [26].

\subsection{Luminescence Spectroscopy}

Luminescence features were observed in the Raman spectra of spinel in Figure 2. Luminescence bands at $677,685,697,710$, and $718 \mathrm{~nm}$ were assigned to $\mathrm{Cr}^{3+}$ [21]. Highly increased intensity of spinel luminescent bands is associated with a laser effect that occurs at $685 \mathrm{~nm}$ [28]. The luminescence spectrum of spinel usually has three parts: (a) the purely electronic R-lines, assigned collectively to the most intense centers [29]; (b) a series of $\mathrm{N}$-lines (Stokes or anti-Stokes line) associated with eight $\mathrm{Cr}^{3+}-\mathrm{Cr}^{3+}$ pair interactions and with $\mathrm{Cr}^{3+}$ at sites differing from the primary site, the concentration-dependent $\mathrm{N}$-lines are caused by chromium pairs, the structure-dependent $\mathrm{N}$-lines arise from six coordinated $\mathrm{Cr}^{3+}$ ions whose short range orders are distorted [30]; (c) series of phonon side bands on the low energy side of the R-lines that relate to the vibrational modes of the spinel crystal [29].

Thus, for a mineral to be luminescent the following three conditions must be satisfied at once: (1) a suitable type of crystal lattice favorable to form emission centers; (2) sufficient content of luminescence centers and (3) a small number of quenchers. The most important quenchers in minerals are $\mathrm{Fe}^{2+}, \mathrm{Co}^{2+}$, and $\mathrm{Ni}^{2+}$, which have intense charge-transfer bands [21], while $\mathrm{Fe}^{3+}$ forms luminescent centers with concentrations up to approximately $1 \%$ [31]. Ferrous iron replaces $\mathrm{Mg}^{2+}$ at the tetrahedral site and $\mathrm{Fe}^{3+}$ substitutes $\mathrm{Al}^{3+}$ at the octahedral site [32]. Differences in shift are minimal, but the biggest difference is in the intensity of bands (Figure 2). Different luminescence intensities are due to the variable content of Fe (Table 2) which quenches the luminescence intensity. This quenching occurs because the energy is transferred from $\mathrm{Cr}^{3+}$ to $\mathrm{Fe}^{2+}$ and is transformed to heat [33].

Spinel SPV-1, 2, and 3 samples from Vietnam have the most intense luminescence resulting from the highest content of $\mathrm{Cr}^{3+}\left(0.0020 .006 \mathrm{apfu}, 0.12-0.31 \mathrm{wt} . \% \mathrm{Cr}_{2} \mathrm{O}_{3}\right)$. The SPV-2 sample with 0.006 apfu $\mathrm{Cr}^{3+}, 0.008$ apfu $\mathrm{Fe}^{3+}$, and $\mathrm{Fe}^{2+}$ below 0.001 apfu has the 
highest intensity within all the samples studied. Other spinels from Vietnam are very similar with very intense $\mathrm{Cr}^{3+}$ luminescence, which cannot be effectively quenched at the almost absent $\mathrm{Fe}^{2+}$.

However, there is not a straightforward dependence of $\mathrm{Cr}^{3+}$ content and the luminescence intensity in spinels from Mogok. The SP-M2 sample has the most intensive luminescence bands. Although the $\mathrm{Cr}^{3+}$ is not very abundant $\left(0.001 \mathrm{apfu} \mathrm{Cr}^{3+}, 0.06 \mathrm{wt} . \%\right.$ $\left.\mathrm{Cr}_{2} \mathrm{O}_{3}\right)$, the $\mathrm{Fe}^{2+}$ content $\left(0.001 \mathrm{apfu} \mathrm{Fe}{ }^{2+}, 0.05 \mathrm{hm} . \% \mathrm{FeO}\right.$ ) is not high enough for the effective quenching of the luminescence. Although the intensity of luminescence is related to the $\mathrm{Cr}^{3+}$ content, $\mathrm{Fe}^{2+}$ must also be considered. This is the case of the SP-M8 sample with a moderate luminescence intensity. The content of $\mathrm{Fe}^{2+}(0.013 \mathrm{apfu}, 0.65 \mathrm{wt} . \% \mathrm{FeO})$ is relatively higher compared to previously mentioned samples, however, still not sufficient to completely quench luminescence of $\mathrm{Cr}^{3+}\left(0.001 \mathrm{apfu}, 0.03 \mathrm{wt} . \% \mathrm{Cr}_{2} \mathrm{O}_{3}\right)$ and $\mathrm{Fe}^{3+}$ (0.006 apfu, 0.36 wt. $\left.\% \mathrm{Fe}_{2} \mathrm{O}_{3}\right)$ luminescent centers. Similarly, in SP-M7, $\mathrm{Fe}^{2+}(0.017 \mathrm{apfu}$, $0.85 \mathrm{hm} . \% \mathrm{FeO}$ ) has even higher contents than $\mathrm{SP}-\mathrm{M} 8$, its intensity is significantly lower. The SP-M9 sample with low amount of $\mathrm{Cr}^{3+}\left(\mathrm{Cr}_{2} \mathrm{O}_{3} 0.02 \mathrm{wt} . \%\right)$ has the least intense luminescence; the content of $\mathrm{Fe}^{2+}$ (0.002 apfu, $\mathrm{FeO} 0.11$ wt.\%), although not the highest among studied samples, contributed to the effective reduction of luminescence. In this case, $\mathrm{Fe}^{3+}$ is not in the position of the luminescent center but rather contributes to its reduction.

\subsection{Optical Absorption Spectroscopy}

Colors of spinels can be explained by the crystal field formalism which involves predominantly ionic crystals containing ions with unpaired electrons, elements with partially filled d shells: V, Cr, $\mathrm{Mn}, \mathrm{Fe}, \mathrm{Co}, \mathrm{Ni}$, and $\mathrm{Cu}$. From these transition elements, iron is the dominant color contributor in minerals [34].

Octahedrally coordinated $\mathrm{d}^{5}$ ions $\left(\mathrm{Fe}^{3+}, \mathrm{Mn}^{2+}\right)$ exhibit no ground-state crystal-field splitting and are not expected to show any colors. Their compounds are weakly colored at the best due to other factors. The free-ion ground state of octahedrally coordinated $\mathrm{d}^{6}$ ions $\left(\mathrm{Fe}^{2+}\right)$ splits into two, and these ions will show one absorption band, corresponding to a transition between these two energy levels. If all or part of this band is in the visible region, compounds containing these cations will display color. The $\mathrm{d}^{2}\left(\mathrm{~V}^{3+}\right)$ and $\mathrm{d}^{3}\left(\mathrm{Cr}^{3+}\right)$ ions have two free-ion terms of the same multiplicity, ${ }^{3} \mathrm{~F}$ and ${ }^{3} \mathrm{P}$ for $\mathrm{d}^{2}$, and ${ }^{4} \mathrm{~F}$ and ${ }^{4} \mathrm{P}$ for $\mathrm{d}^{3}$. In the crystal field, the ${ }^{3} \mathrm{P}$ or ${ }^{4} \mathrm{P}$ states with the higher energy give rise to ${ }^{3} \mathrm{~T}_{1 \mathrm{~g}}$ and ${ }^{4} \mathrm{~T}_{1 \mathrm{~g}}$ states. Spin-allowed transitions to these additional energy levels give rise to three absorption bands in the case of $\mathrm{V}^{3+}$. In $\mathrm{Cr}^{3+}$ ions, the transition to the ${ }^{4} \mathrm{~T}$ state is at a high energy and is not recorded in the visible spectrum [35].

According to their dominant chromophore, the studied spinels can be divided to vanadium-chromium and iron spinels.

\subsubsection{V and Cr Spinels}

Vanadium-chromium or chromium-vanadium-bearing spinel samples (Figure 3) show a color typically changing from orange to red or magenta [22].

The optical spectra of this group spinels are approximately similar, consisting of the main absorption band, which is divided into two regions, absorption in the infrared region and sharp but weak absorption in the ultraviolet region. In Table 4, absorption bands are assigned to the dominant chromophores, or interactions. For SP-M1, SP-M2, SP-M4, SPM5, and SP-M6 (Figure 3a-e) spinels with dominant vanadium, the first absorption bands at 424-468 and 542-554 nm were assigned to spin allowed $d-d^{3} \mathrm{~T}_{1 \mathrm{~g}}\left({ }^{3} \mathrm{~F}\right) \rightarrow{ }^{3} \mathrm{~T}_{1 \mathrm{~g}}\left({ }^{3} \mathrm{P}\right)$ and ${ }^{3} \mathrm{~T}_{1 \mathrm{~g}}\left({ }^{3} \mathrm{~F}\right) \rightarrow{ }^{3} \mathrm{~T}_{2}\left({ }^{3} \mathrm{~F}\right)$ transitions in $\mathrm{V}^{3+}$ at the $M$ sites. Chromium-enriched spinel (SPV-1-3) absorption bands at $424-448$ and $541-543 \mathrm{~nm}$ were assigned to spin-allowed $d-d$ transition ${ }^{4} \mathrm{~A}_{2 \mathrm{~g}} \rightarrow{ }^{4} \mathrm{~T}_{1 \mathrm{~g}}\left({ }^{4} \mathrm{~F}\right)$ and ${ }^{4} \mathrm{~A}_{2 \mathrm{~g}} \rightarrow{ }^{4} \mathrm{~T}_{2 \mathrm{~g}}\left({ }^{4} \mathrm{~F}\right)$ in $\mathrm{Cr}^{3+}$ at the $M$ sites (Figure $3 \mathrm{f}-\mathrm{h}$ ). All the spectra studied had weaker and broad absorption band in infrared region, caused by oxygen to metal $\mathrm{O}^{2-}-\mathrm{Fe}^{2+}$ electronic charge transfer transition [22].

The color of spinel depends on the concentration of chromophores and their interactions in the structure. Vanadium dominant spinels are orange, red, pink and their various 
shades. Orange-colored SP-M2 and SP-M6 spinels with the increased iron content have broad absorption band without significant transmission in the blue region. The pinkshaded SP-M1 and SP-M4 samples are similar, only SP-M4 has stronger transmission at $480 \mathrm{~nm}$ (blue region) and $620 \mathrm{~nm}$ causing a strong purplish pink color. Chromium content in this sample causes more intensive transmission in the yellow-green region, while SP-M1 has Cr below the detection limit. Red spinel SP-M5 has absorption band shifted to $480 \mathrm{~nm}$. Transmission occurs from $600 \mathrm{~nm}$ to NIR region. The SP-M5 sample has the highest contents of $\mathrm{V}, \mathrm{Cr}$, and also Fe. The high iron and vanadium contents result in a very saturated and dark color of the spinel.

Spinels from Vietnam are pink to red with different shades but have usually higher $\mathrm{Cr}$ than $\mathrm{V}$ content (Table 1). The SPV-1 sample has relatively stronger absorption in blue to green region than SPV-2; thus, SPV-1 is red and SPV-2 intensively pink. The SPV-3 sample has relatively strong absorption in the whole visible light spectrum due to the highest content of $\mathrm{Fe}$ and the lowest contents of $\mathrm{Cr}$. Consequently, the color of this sample is grey.

In the NIR region at around $770-800 \mathrm{~nm}$, the studied samples display broad absorption band likely associated with $\mathrm{Fe}^{2+}$ spin-forbidden ${ }^{5} \mathrm{E} \rightarrow{ }^{3} \mathrm{~T}_{1}$ electron transition [22].

\subsubsection{Fe Spinels}

Iron in spinels occurs in two valence states- $\mathrm{as} \mathrm{Fe}^{3+}$ and $\mathrm{Fe}^{2+}$ [34]. Iron is the main chromophore among the iron group of studied spinels. The differences in spectra result from variations in the $\mathrm{Fe}^{3+} / \mathrm{Fe}^{2+}$ ratio, and also from the presence of minor $\mathrm{Cr}^{3+}$ and $\mathrm{V}^{3+}$. Studied iron spinels can be divided into two types: $\mathrm{Fe}^{3+}$-dominant SP-M3 and SP-M9 samples (Figure 4a,d) and $\mathrm{Fe}^{2+}$ dominant SP-M7 and SP-M8 samples (Table 5, Figure 4b,c). Spinels containing $\mathrm{Fe}^{2+}$ have shades of blue $(\mathrm{SP}-\mathrm{M} 7,8)$ and samples with predominant $\mathrm{Fe}^{3+}$ content have shades of pink to yellow (SP-M3,9).

Absorption bands in spinel spectra are likely caused by electronic transitions in isolated $\mathrm{Fe}^{2+}$ and $\mathrm{Fe}^{3+}$ cations, as well as by pairs of $\mathrm{Fe}$ ions $[36,37]$. The absorption bands at 464 and $461 \mathrm{~nm}$ can be attributed to ${ }^{6} \mathrm{~A}_{1 \mathrm{~g}} \rightarrow{ }^{4} \mathrm{~A}_{1 \mathrm{~g}},{ }^{4} \mathrm{E}_{\mathrm{g}}\left({ }^{4} \mathrm{G}\right)$ transition in ${ }^{\mathrm{VI}} \mathrm{Fe}^{3+}$ [36]. However, it is not excluded that, at least partly, absorption may be intensified by exchangecoupled interaction in $\mathrm{Fe}^{3+}-\mathrm{Fe}^{3+}$ pairs [37]. Therefore, we cannot discriminate between electronic transitions in isolated ions and electron exchange in coupled pairs of $\mathrm{Fe}^{3+}$ as the cause of these band in spectra of spinels. The intensity of these band does not strictly correlate with the amount of $\mathrm{Fe}^{3+}$.

This discrepancy may be because in iron-enriched spinels, a part of ferric iron enters tetrahedral sites of the spinel structure. In such case, oscillator strength of the electronic transition of tetrahedral ions may be several orders of magnitude higher than in octahedral [36] and the proper absorption bands may be significantly enhanced [37]. Energy of ${ }^{6} \mathrm{~A}_{1 \mathrm{~g}} \rightarrow{ }^{4} \mathrm{~A}_{1 \mathrm{~g}},{ }^{4} \mathrm{E}_{\mathrm{g}}$ transition may be very similar in ${ }^{\mathrm{VI}} \mathrm{Fe}^{3+}$ and ${ }^{\mathrm{IV}} \mathrm{Fe}^{3+}$, and therefore both transitions may be seen as a single band in the spectra [37]. In the spectra of low-iron spinels, these bands may also be caused by spin-forbidden transitions of tetrahedral $\mathrm{Fe}^{2+}$. Therefore, in most cases this relatively sharp distinct peak in spinel spectra is a superposition of two or even three bands of close energies, caused by spin-forbidden transitions [38]. Samples SP-M7 and SP-M8 with the highest $\mathrm{Fe}^{2+}$ contents ( 0.17 and $0.13 \mathrm{apfu}$ ) have the most intensive absorption in this area. In contrast, SP-M3 sample has the lowest iron content from Fe-spinels and the absorption band at $464 \mathrm{~nm}$ is negligible.

Absorption bands at $541-557 \mathrm{~nm}$ in the SP-M3, 7, 8 samples belong to the spin forbidden transition ${ }^{5} \mathrm{E}(\mathrm{D}) \rightarrow{ }^{3} \mathrm{~T}_{2}(\mathrm{H})$ of $\mathrm{Fe}^{2+}[37,39,40]$. Bands at 639-647 $\mathrm{nm}$ are assigned to ${ }^{\mathrm{VI}} \mathrm{Fe}^{2+}{ }^{\mathrm{VI}} \mathrm{Fe}^{3+}$ IVCT and/or ${ }^{\mathrm{VI}} \mathrm{Fe}^{2+}{ }^{2 \mathrm{IV}} \mathrm{Fe}^{3+}$ exchange-coupled pair transitions [39,41]. This argument is well supported by the presence of the absorption band at 908-932 nm attributed to a spin-allowed transition ${ }^{5} \mathrm{~T}_{2 \mathrm{~g}} \rightarrow{ }^{5} \mathrm{E}_{\mathrm{g}}$ in ${ }^{\mathrm{VI}} \mathrm{Fe}^{2+}[39-41]$. 


\section{Conclusions}

Spectroscopic comparison of spinels showed a direct influence of transition metals (luminophores and chromophores) on spectra. The chemical composition and chromophores, luminophores in the structure largely affects the resulting spectra. The effect of luminophores on luminescence spectra was most pronounced in intensity. The dependence of the number of luminophores and the intensity of luminescence was confirmed, where Fe acted predominantly as a quencher. We have seen the effect of quenching but also the enhancement of luminescence due to $\mathrm{Cr}^{3+}$. Optical spectra were divided according to the dominant chromophore into $\mathrm{V}$ and $\mathrm{Cr}$ spinels, Fe spinels. These differences visible in the spectra and the chemical composition has confirmed this division.

Author Contributions: Concept of study, I.M., P.B., J.F., and R.H.; methodology, I.M., P.B., J.F., L.I., J.Š., D.F., S.F., and R.Š.; investigation, I.M., P.B., J.F., and R.H.; compilation and writing of the manuscript, I.M., P.B., and J.F.; review and editing, I.M., P.B., and J.F. All authors have read and agreed to the published version of the manuscript.

Funding: This research was funded by the Slovak Research and Development Agency under the Contract, number APVV-18-0065 and by the Ministry of Education of Slovak Republic grant agency under the contract VEGA-1/0137/20.

Data Availability Statement: Data is contained within the article.

Conflicts of Interest: The authors declare no conflict of interest.

\section{References}

1. D'Ippolito, V.; Andreozzi, G.B.; Hålenius, U.; Skogby, H.; Hametner, K.; Günther, D. Color mechanisms in spinel: Cobalt and iron interplay for the blue color. Phys. Chem. Miner. 2015, 42, 431-439. [CrossRef]

2. Anthony, J.W.; Bideaux, R.A.; Bladh, W.; Nichols, M.C. Handbook of Mineralogy; Mineralogical Society of America: Chantilly, VA, USA, 2017; Available online: http:/ / www.handbookofmineralogy.org/ (accessed on 19 February 2020).

3. Bosi, F.; Biagioni, C.; Pasero, M. Nomenclature and classification of the spinel supergroup. Eur. J. Mineral. $2019,31,183-192$. [CrossRef]

4. Uchida, H.; Lavina, B.; Downs, R.T.; Chesley, J. Single-crystal X-ray diffraction of spinels from the San Carlos Volcanic Field, Arizona: Spinel as a geothermometer. Am. Mineral. 2005, 90, 1900-1908. [CrossRef]

5. Cynn, H.; Sharma, S.K.; Cooney, T.F.; Nicol, M. High-temperature Raman investigation of order-disorder behavior in the $\mathrm{MgAl}_{2} \mathrm{O}_{4}$ spinel. Phys. Rev. B 1992, 45, 500-502. [CrossRef]

6. Busca, G.; Lorenzelli, V.; Ramis, G.; Willeyi, R.J. Surface Sites on Spinel-Type and Corundum-Type Metal Oxide Powders. Am. Chem. Soc. 1993, 9, 1492-1499. [CrossRef]

7. Hazen, R.M.; Yang, H. Effect of cation substitution and order-disorder on P-V-T equations of state of cubic spinels. Am. Mineral. 1999, 84, 1956-1960. [CrossRef]

8. Kušnír, I. Mineral resources of Vietnam. Acta Montan. Slovaca 2000, 5, 165-172.

9. Garnier, V.; Ohnenstetter, D.; Giuliani, G.; Maluski, H.; Deloule, E.; Phan Trong, T.; Pham Van, L.; Hoàng Quang, V. Age and significance of ruby-bearing marble from the Red River Shear Zone, northern Vietnam. Can. Mineral. 2005, 43, 1315-1329. [CrossRef]

10. Leloup, P.H.; Arnaud, N.; Lacassin, R.; Kienast, J.R.; Harrison, T.M.; Phan Trong, T.T.; Replumaz, A.; Taponnier, P. New constraints on the structure, thermochronology, and timing of the Ailo Shan-Red River shear zone, SE Asia. J. Geophys. Res. Atmos. 2001, 106, 6683-6732. [CrossRef]

11. Garnier, V.; Giuliani, G.; Ohnenstetter, D.; Fallick, A.E.; Dubessy, J.; Banks, D.; Vinh, H.Q.; Lhomme, T.; Maluski, H.; Pêcher, A.; et al. Marble-hosted ruby deposits from Central and South-East Asia: Toward a new genetic model. Ore Geol. Rev. 2008, 34, 169-191. [CrossRef]

12. Chauviré, B.; Rondeau, B.; Fritsch, E.; Ressigeac, P.; Devidal, J.L. Blue spinel from the Luc Yen district of Vietnam. Gems Gemmol. 2015, 51, 2-17. [CrossRef]

13. Long, P.V.; Pardieu, V.; Giuliani, G. Update on gemstone mining in Luc Yen, Vietnam. Gems Gemmol. 2013, 49, 233-245. [CrossRef]

14. Barley, M.E.; Pickard, A.L.; Za, K.; Rak, P.; Doyle, M.G. Jurassic to Miocene magmatism and metamorphism in the Mogok Metamorphic Belt and the India-Eurasia collision in Myanmar. Tectonics 2003, 22, 1-11. [CrossRef]

15. Searle, M.P.; Noble, S.R.; Cottle, J.M.; Waters, D.J.; Mitchell, A.H.G.; Hlaing, T.; Horstwood, M.S.A. Tectonic evolution of the Mogok Metamorphic Belt, Burma (Myanmar) constrained by U-Th-Pb dating of metamorphic and magmatic rocks. Tectonics 2007, 26, 1-24. [CrossRef] 
16. Thu, K. The Igneous Rocks of the Mogok Stone Tract: Their Distributions, Petrography, Petrochemistry, Sequence, Geochronology and Economic Geology. Ph.D. Thesis, Department of Geology, University of Yangon, Yangon, Myanmar, 2007. Available online: http:/ / m.palaminerals.com/mogok (accessed on 17 December 2020).

17. Iyer, L.A.N. The geology and gemstones of the Mogok Stone Tract, Burma. Mem. Geol. Surv. India 1953, 82, 100.

18. Thein, M. Modes of occurrence and origin of precious gemstone deposits of the Mogok Stone Tract. J. Myanmar Geosci. Soc. 2008, $1,75-84$.

19. Mogok Township, Pyin-Oo-Lwin District, Mandalay Region, Myanmar. Available online: https://www.mindat.org/loc-24345. html (accessed on 24 February 2019).

20. Chopelas, A.; Hofmeister, A.M. Vibrational spectroscopy of aluminate spinels at $1 \mathrm{~atm}$ and of $\mathrm{MgAl}_{2} \mathrm{O}_{4}$ to over $200 \mathrm{kbar} . P h y s$. Chem. Miner. 1991, 18, 279-293. [CrossRef]

21. Gaft, M.; Reisfeld, R.; Panczer, G. Modern Luminescence Spectroscopy of Minerals and Materials, 2nd ed.; Springer: Berlin/Heidelberg, Germany, 2015; p. 606.

22. Andreozzi, G.B.; D’Ippolito, V.; Skogby, H.; Hålenius, U.; Bosi, F. Color mechanisms in spinel: A multi-analytical investigation of natural crystals with range of coloration. Phys. Chem. Miner. 2018, 42, 431-439. [CrossRef]

23. Lazzeri, M.; Thibaudeau, P. Ab initio Raman spectrum of the normal and disordered $\mathrm{MgAl}_{2} \mathrm{O}_{4}$ spinel. Phys. Rev. B 2006, 74, 140301. [CrossRef]

24. Slotznick, S.P.; Shim, S.H. In situ Raman spectroscopy measurements of $\mathrm{Mg} \mathrm{Al}_{2} \mathrm{O}_{4}$ spinel up to $1400{ }^{\circ} \mathrm{C}$. Am. Mineral. 2008, 93, 470-476. [CrossRef]

25. Widmer, R.; Malsy, A.K.; Armbruster, T. Effect of heat treatment on red gemstone spinel: Single- crystal X-ray, Raman, and photoluminescence study. Phys. Chem. Miner. 2015, 42, 251-260. [CrossRef]

26. Phyo, M.M.; Bieler, E.; Franz, L.; Balmer, W.; Krzemnicki, M.S. Spinel from Mogok Myanmar-A detailed inclusion study by Raman Microspectroscopy and Scanning Electron Microscopy. J. Gemol. 2019, 36, 418-435. [CrossRef]

27. Gunasekaran, S.; Anbalagan, G.; Pandi, S. Raman and infrared spectra of carbonates of calcite structure. J. Raman Spectrosc. 2006, 37, 892-899. [CrossRef]

28. Jouini, A. $\mathrm{MgAl}_{2} \mathrm{O}_{4}$ Spinel Laser Crystals: Pure and Ti-, Mn-, or Ni- Doped. Shaped Crystals. In Advances in Materials Research, 8; Fukuda, T., Chani, V.I., Eds.; Springer: Berlin/Heidelberg, Germany, 2007; pp. 203-215.

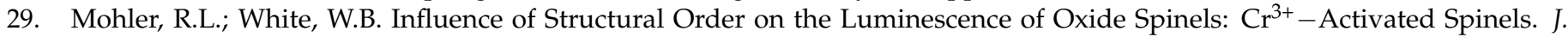
Electrochem. Soc. 1995, 11, 3923-3927. [CrossRef]

30. Derkosch, J.; Mikenda, W.; Preisinger, A. N-Lines and Chromium-Pairs in the Luminescence Spectra of the $\mathrm{Spinels} \mathrm{ZnAl}_{2} \mathrm{O}_{4}$ : $\mathrm{Cr}^{3+}$ and $\mathrm{MgAl}_{2} \mathrm{O}_{4}: \mathrm{Cr}^{3+}$. J. Solid State Chem. 1977, 22, 127-133. [CrossRef]

31. Tarashchan, A. Luminescence of Minerals; Naukova Dumka: Kiev, Ukraine, 1978. (In Russian)

32. De Souza, S.S.; Ayres, F.; Blak, A.R. Simulation models of deffects in $\mathrm{MgAl}_{2} \mathrm{O}_{4}: \mathrm{Fe}^{2+}, \mathrm{Fe}^{3+}$ spinels. Radiat. Eff. Defects Solids 2001, 156, 311-316. [CrossRef]

33. Nassau, K. The Physics and Chemistry of Color, 2nd ed.; John Wiley \& Sons, Inc.: Etobicoke, ON, Canada, 1983 ; p. 454.

34. Nassau, K. The origins of color in minerals. Am. Mineral. 1978, 63, $219-229$.

35. Tilley, R.J.D. Transition-Metal Ion Colors. In Encyclopedia of Color Science and Technology; Springer Science: New York, NY, USA, 2013; pp. 1-10.

36. Burns, R.G. Mineralogical Applications of Crystal Field Theory, 2nd ed.; Cambridge University Press: Cambridge, UK, 1993 ; p. 576.

37. Taran, M.N.; Koch-Müller, M.; Langer, K. Electronic absorption spectroscopy of natural $\left(\mathrm{Fe}^{2+}\right.$, $\left.\mathrm{Fe}^{3+}\right)$-bearing spinels of spinel s.s.-hercynite and gahnite-hercynite solid solutions at different temperatures and high-pressures. Phys. Chem. Miner. 2005, 32, 175-188. [CrossRef]

38. Dickson, B.L.; Smith, G. Low temperature optical absorption and Mössbauer spectra of staurolite and spinel. Can. Mineral. 1976, 14, 206-215.

39. Schmetzer, K.; Haxel, C.; Bank, H. Colour of natural spinels, gahnospinels and gahnites. Neues Jahrb. Mineral. 1989, 160, 159-180.

40. Fregola, R.A.; Skogby, H.; Bosi, F.; D’Ippolito, V.; Andreozzi, G.B.; Hålenius, U. Optical absorption spectroscopy study of the causes for color variations in natural Fe-bearing gahnite: Insights from iron valency and site distribution data. Am. Mineral. 2014, 99, 2187-2195. [CrossRef]

41. Hålenius, U.; Skogby, H.; Andreozzi, G.B. Influence of cation distribution on the optical absorption spectra of Fe ${ }^{3+}$-bearing spinel s.s.-hercynite crystals: Evidence for electron transitions in ${ }^{\mathrm{VI}} \mathrm{Fe}^{2+}{ }^{\mathrm{VI}} \mathrm{Fe}^{3+}$ clusters. Phys. Chem. Miner. 2002, 29, 319-330. 